\title{
Qualification of offshore facilities prior to application in a new field
}

\author{
S. M. S. M. K. Samarakoon ${ }^{1}$, O. T. Gudmestad ${ }^{1} \&$ M. S. L. Melhus ${ }^{2}$ \\ ${ }^{I}$ Faculty of Science and Technology, University of Stavanger, Norway \\ ${ }^{2}$ Eni Norge AS, Norway
}

\begin{abstract}
A strict emission regime for marine operations in Norwegian Continental Shelf (NCS), increasing fuel prices and tax on environmental emissions, have led to a need to consider alternative solutions for supplying power for offshore oil and gas installations. Conventionally, natural gas and diesel are used for the production of electricity on offshore installations. However, this conventional approach has developed into a real burden, as it conflicts with the aim of achieving least emission to the environment. Electrification has been considered as one of the alternatives to cut down the emission level to a reasonable extent as well as to increase the power supply efficiency. This analysis deals with electrification of new facilities, while the cost of electrification of existing facilities has not been estimated yet. Although electrification might be selected as the best available technique for a given field, it is necessary to assure that the electrification technique will be fit for the purpose if it is going to be implemented in an unknown environment. This paper will address a method to qualify the electrification technique for a new oil field development on the NCS. Further, this study will help to confirm that the Best Available Technique (BAT) should be qualified prior to the implementation to avoid consequence of harm to the environment, society, health and finances.
\end{abstract}

Keywords: BAT, qualification of technique, emission, electrification.

\section{Introduction}

An important engineering challenge of today, and a vital one for the future, is equal consideration of HSE (Health, Safety and Environment) aspects and industrial interests in decision-making processes. This means that the companies 
must adapt the best qualified choice of installation, equipment, production methods, management systems, barriers and emergency preparedness providing a high level of assurance of no consequence of harm to the environment. Recently, environmental protection has been paid major attention in the case of evaluating power supply systems for offshore oil and gas installations.

Therefore, supplying power from the shoreline (electrification) to the offshore facilities has been considered as one of the attractive and environmentally friendly alternative techniques [1, 2]. But, supplying power from land-based sources to all offshore installations for the oil and gas industry has been a difficult technical task. Basically, most of the offshore facilities on the NCS have been fulfilling the power requirement by using gas turbines since the beginning of the field developments. However, some of the offshore facilities - especially for new developments - on the NCS have been selected electrification solution as the Best Available Technique, for instance, Troll A, Valhall, Gjøa, Goliat and Ormen Lange. Further, the petroleum sector accounts for about $25 \%$ of Norwegian emissions of greenhouse gases based on the 2006 estimation [1]. Hence, electrification; the supply of power from land to the offshore installation has been paid major attention in Norway in particular as $100 \%$ of electricity generation is based on clean hydro power. In addition, there is also a possibility to import electricity from Europe.

When electrification has been considered as the BAT for the particular field, it is required to confirm its "fitness for the purpose" prior to the application. This is due to the fact that electrification will be evaluated for all new developments, and that the technical and economical issues related to electrification of new facilities are different from those for existing facilities. This means that technique qualification is playing a vital role. This study initially discusses the reasons for seeking alternative power supply systems as well as the concepts of BAT. Then, the next section describes the technique qualification and methods to use. Its applicability will be discussed in the following section using a case study from the NCS. Finally, results and discussions as well as conclusions are presented.

\section{Reasons for seeking alternative solutions for power supply for offshore installations}

\subsection{Emission control}

The most significant emission sources from the oil and gas industry are flares and power generation, produced water discharge, cuttings from drilling activities and crude oil spills $[4,5]$. Further, $\mathrm{CO}_{2}, \mathrm{NO}_{\mathrm{x}}$ and volatile organic compounds are noteworthy emissions to air on the NCS. A large part of the offshore $\mathrm{CO}_{2}$ emissions, about $75 \%$ of the total emissions to air from offshore installations, stem from the direct drive compressors, power turbine production and combustion engines on the platforms [3]. The emissions are about to increase as a consequence of more energy-demanding operations, more fields entering into a mature phase with greater water production and an increase in distances for gas 
transportation from the new field. The Gothenburg Protocol, entered into in 2005, aims that Norway shall reduce $\mathrm{NO}_{\mathrm{x}}$ emissions by $27 \%$ compared to 1990 emission levels in 2010 [3]. Furthermore, Norway's Kyoto obligations direct that emissions of greenhouse gases shall not surpass 50.6 million tonnes per year of $\mathrm{CO}_{2}$-equivalents on average during the period 2008-2012 [1]. As per these tight targets, the Norwegian government has put pressure on industries to find best practices for their industrial activities.

Emissions and discharges from petroleum activities in Norway are regulated by the Petroleum Act, the $\mathrm{CO}_{2}$ Tax Act, the Greenhouse Gas Emission Trading Act and the Pollution Control Act [3]. Further, $\mathrm{CO}_{2}$ taxation has led to development of new techniques and triggered initiatives that lead to considerable emission reductions. The strict regulation of flaring through the Petroleum Act contributes to a low general level of flaring on the NCS, compared with other countries. Further, the BAT concept has been included in the Norwegian Pollution Control Act, applying to installations in Norway [2]. Similarly, implementation of BAT has been accelerating in oil and gas operations in Norway due to the introduction of a requirement for "zero discharge to sea" [68], pressure developed from stakeholders to address the environmental aspects [1] as well as ambitious HSE policies in companies.

\subsection{Other reasons}

The power demand on offshore installation depends on the equipment and the processes on the installation. On most offshore installations, power supply generators and large compressors are driven by onboard gas turbines or diesel engines. Many of these have total efficiencies as low as $20-25 \%$ under the best of conditions, resulting in high emission and high power consumption [9]. However, the most of the gas turbines used in the NCS have improved to achieve about $41 \%$ of total efficiency [2]. Further, the offshore salty environment leads to higher maintenance costs. An increase in gas prices has also caused companies to find economically feasible alternative power supply source.

\section{Concept of BAT and requirement of qualified technique}

In connection with the introduction of the IPPC (Integrated Pollution Prevention and Control) Directive [12], the Norwegian Petroleum Directorate (NPD) cooperated with the Norwegian Pollution Control Authority on the status, alternatives and costs associated with increased energy efficiency and implementation of emission-reducing measures using the BAT concept. Further, BAT determination should be carried out by the screening and assessment of technologies and techniques with respect to all the aspects provided in the directives. Once the BAT evaluation is finalized, it will be used for the determination of emission limit values and for granting of permits for installations $[10,11]$. It also allows for dynamic adjustments to new technological achievements. 


\subsection{Clarification of BAT [12]}

- "Techniques" shall include both the technology used and the way in which the installation is designed, built, maintained, operated and decommissioned

- "Available" techniques shall mean those developed on a scale which allows implementation in the relevant industrial sector, under economically and technically viable conditions, taking into consideration the costs and advantages, whether or not the techniques are used or produced inside the member state in question, as long as they are reasonably accessible to the operator.

- "Best" shall mean the most effective in achieving a high general level of protection of the environment as a whole.

IPPC also covers environmental performance of the plant and emissions to air, water and land, generation of waste, use of raw materials, energy efficiency, noise, prevention of accidents, and restoration of the site upon closure. Although the IPPC directives provide guidelines for selecting technologies and techniques for specified industrial activities, it does not provide the guidelines for these technologies or techniques to be qualified in order to meet the reliability and quality requirement of its intended applications [13]. Therefore, it is necessary to have a qualification method prior to application, which identifies the failures and the consequences' effects, to help in modifying the selected techniques.

\section{Technique qualification}

Technology qualification benefits the manufacturer, the company and the enduser by proving the fitness for purpose, evaluating system reliability and optimizing the investment through selecting technologies. The definitions given in the literature for technology qualification are as follows:

"Qualification is the process of verifying and validating the system design and then obtaining the stakeholders' acceptance" [14].

"The process of providing the evidence that the technology will function within specific limits with an acceptable level of confidence" [15].

"Qualification or testing shall demonstrate that applicable requirements can be fulfilled by use of the relevant new technology or new methods" [6].

Based on the above definitions, the following definition is considered in this paper.

"Technique Qualification" shall mean confirmation with provision of evidence that the selected BAT in accordance with the guidelines provided in the authority requirements meets specified requirements during design, installation, operation and performance for the intended use.

Technology qualification procedures reveal opportunities to improve system design, to minimize the schedule risk and to reduce risk costs during operations by reducing uncertainties and increasing reliability. The qualification process 
identifies and documents any shortcomings of the new or improved technology that would prevent it from fulfilling the functional and performance requirements with respect to production, health, safety, environment and reliability throughout its complete life cycle, and is applicable for all levels of the project (e.g. system, subsystem, component and part) as well as all project phases.

This is the general case, although the Petroleum Safety Authority of Norway [6] in their Facilities Regulation, Chapter 3, Section 8, prescribes qualification in case new technology and new methods are used: "Where the petroleum activities involve use of new technology or new methods, criteria shall be prepared with regard to development, testing and use in order to fulfill the requirements to health, environment and safety". However, it should also be required to qualify proven techniques when it is going to be applied for a new environment [15]. For instance, in Norway, the oil and gas exploration and production is carried out offshore and there are new fields under development. Environmental conditions and engineering aspects are rather different from field to field. It is vital to identify the failure modes for the techniques selected and identify mitigation effects prior to application in the case of both new techniques and proven techniques being applied for a new environment.

\subsection{Method for qualification of techniques}

A technique qualification procedure involves a technique qualification plan and technique assessment [13]. This paper advocates using FMECA (Failure Modes, Effect and Criticality Analysis) for technique assessment to minimize the risk when applying the technique in a new environment. FMECA can be examined on two levels [16]. In the first level of analysis, it consists of the identification of potential failure modes of the constituent items (components or sub-systems) and the effect on the system performance by identifying the potential severity of the effect. The second level of analysis is a criticality analysis and criticality ranking of the items under investigation. Both of these levels are intended to provide information for making risk management decisions. This analysis should be performed iteratively in all stages of the design and operation of a system and figure 1 shows the basic steps involved in the FMECA process.

\section{BAT; supplying power from land (electrification)}

The electrical power supply on an oil production platform is regarded as an auxiliary system, designed to supply the platform with the necessary electric power throughout its lifetime with sufficient reliability and availability. The power system consists of the main power system, the essential power system and the emergency power system. In the case of the main power being supplied from shoreline to offshore (Figure 2), there are three diferent alternative systems HVAC (High Voltage Alternative Current), HVDC (High Voltage Direct Current) LCC (Line Commutated Convertor) and HVDC VSC (Voltage Source Converter) in existence to achieve offshore electrical power transmission [17]. Furthermore, the basic selection of power transmission system can be done 
90 Management of Natural Resources, Sustainable Development and Ecological Hazards II

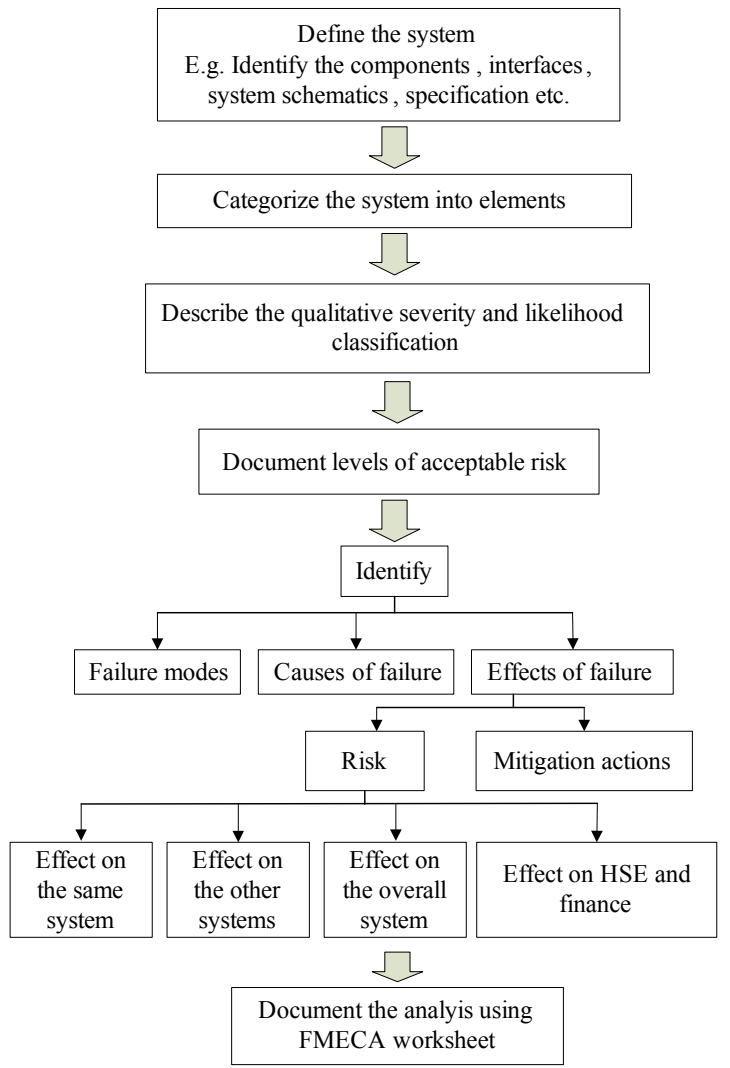

Figure 1: Graphical interpretation of FMECA approach.

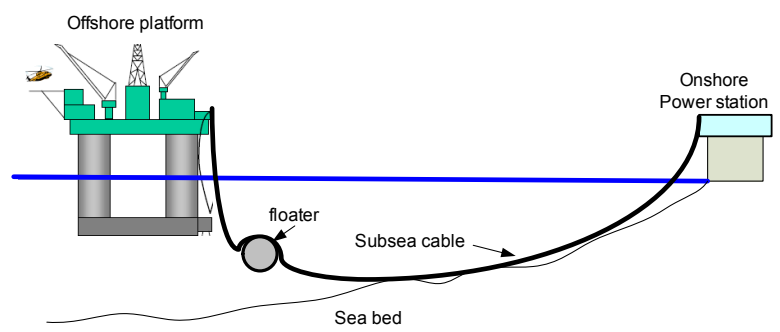

Figure 2: Overview of the electrification of offshore platform.

depending on the location of the oil field and the power requirement as shown in Figure 3. Note that a high effect AC system is not technically feasible for long distances. 


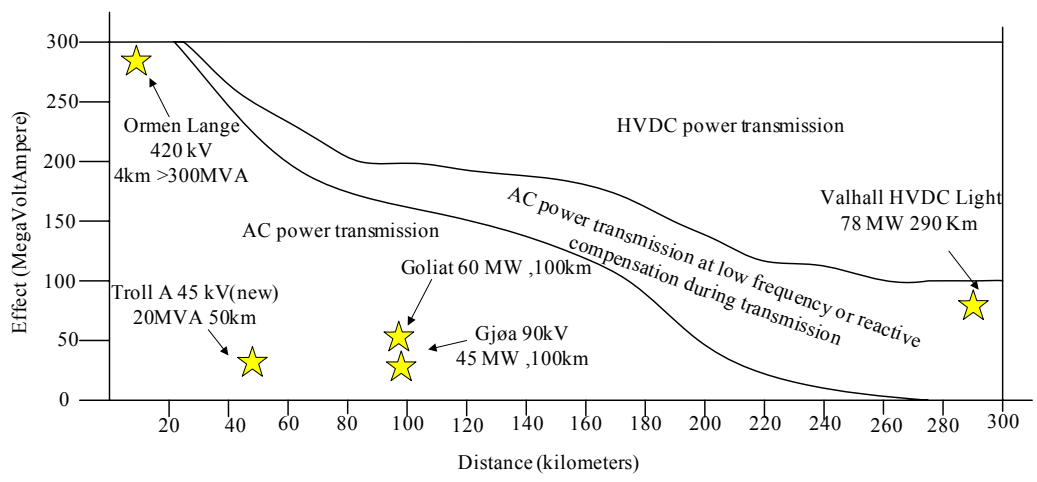

Figure 3: $\quad$ Selection of transmission method for power supply [2].

Electrification of most existing oil fields is not an economically viable solution due to the cost level, complexity of the construction processes and field lifetime [2]. Nevertheless, Troll A, one of the existing installations is being electrified and annual emissions of 230,000 tons of $\mathrm{CO}_{2}$ and 230 tons of $\mathrm{NOx}$ are avoided. [18]. However, in the case of new oil and gas developments, electrification is an important element in efforts to enhance power supply efficiency and reduce $\mathrm{CO}_{2}$ emissions on the Norwegian Continental Shelf (NCS). For instance, the Gjøa platform in the North Sea will be the first floating platform to get its electricity from mainland Norway [19]. The expectation is a reduction in emissions to the environment of 230,000 tons of carbon dioxide per year. In addition, transmission of electrical energy from shore involves less maintenance, longer lifetime and higher availability than gas turbines and diesel engines.

\section{Case study: technique qualification for a new oil field}

The new oil field is situated in the Barents Sea (northern part of Norway) in about $375 \mathrm{~m}$ water depth. The oil discovery was made through exploration wells in year 2000 and resources have been estimated to 27.5 million scm oil and 3.1 billion scm gas [3]. In adition, the licensees have decided to proceed with a development concept based on a Floating Production Storage and Offloading (FPSO) facility tied to subsea level. Moreover, the electrification has been selected as the BAT for satisfy the power demand of $60 \mathrm{MW}$ for the new installation. However, the heat demand $(36 \mathrm{MW})$ is supplied by both electrical heaters connected to power supply from shore and WHRU connected to a Dry Low Emission gas turbine, which is running in parallel.

This means that part of the power demand is proposed to be supplied from conventional gas turbines with heat recovery unit and recycling to provide the necessary process heat (see Figure 3). It should be noted that it is an advantage that the two power supply sources are independent which means that operations can continue, at a reduced capacity, in case of loss of one power source. 
Although the most environmental friendly solution is only dependent on the power from shore, supplying power in independent systems has been chosen for this field based on following factors: emission reduction, independent power sources, high thermal heat demand, availability of shore power, reduced OPEX (Operating Expenditure) costs on power generation systems in offshore, satisfaction of statutory requirements, company standards, international and national standards and high energy efficiency in gas turbines (80-85\%). This provides the foundation to optimize the alternatives. However, this is not sufficient enough to confirm its fitness for the purposes. Therefore, it is essential to evaluate the risk and reliability aspects during design, installation, operation and performance of this technique prior to application.

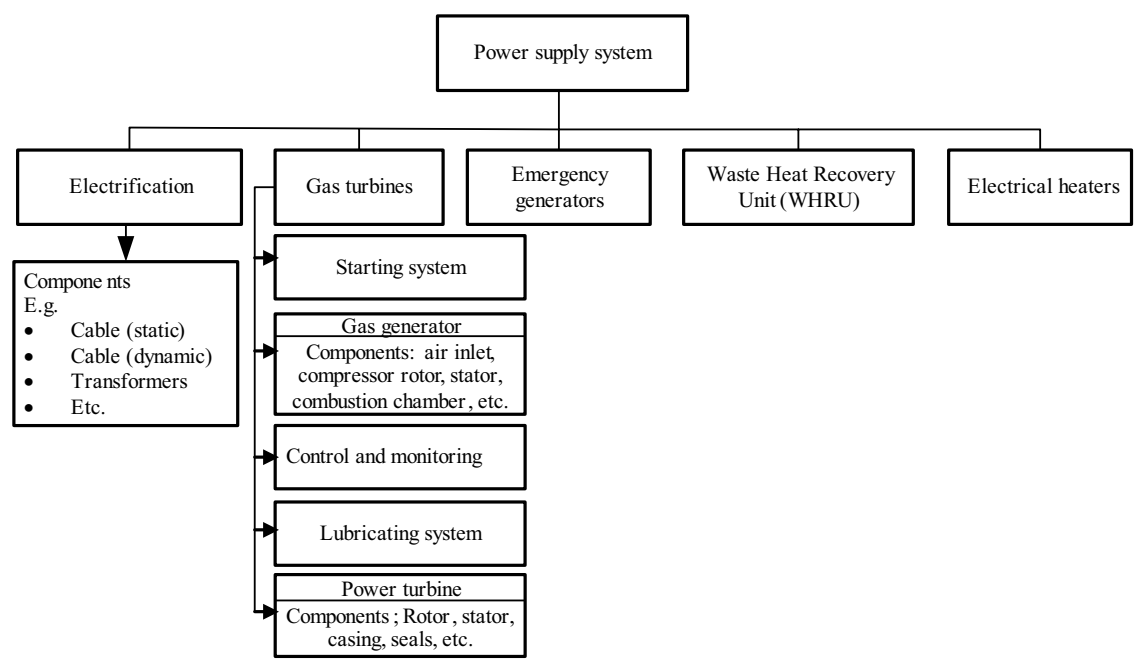

Figure 4: Overview of the power supply system.

It should be noticed that this application of electrification poses new challenges that must be reviewed in the technique qualification process. These include - but are not limited to - the effect of the harsh climate of the northern region [20], the potential limited electric energy available during emergency situations when the onshore grid may be damaged in storms, the potential for free spans of the cable from shore to the platform etc.

Therefore, an FMECA assessment has been illustrated to assess the technique and to identify the modification requirement at the design phase. Figure 4 shows the breakdown of the power supply system into subsystems and it can be further divided into components. Figure 5 shows the risk matrix used and Figure 6 illustrates the FMECA worksheet. 


\begin{tabular}{|c|c|c|c|c|}
\hline Likelihood & $\begin{array}{c}\text { Catastrophic } \\
\text { I }\end{array}$ & $\begin{array}{c}\text { Critical } \\
\text { II }\end{array}$ & $\begin{array}{c}\text { Marginal } \\
\text { III }\end{array}$ & $\begin{array}{l}\text { Negligible } \\
\text { IV }\end{array}$ \\
\hline Frequent (A) & 1 & 3 & 7 & 13 \\
\hline Probable (B) & 2 & 5 & 9 & 16 \\
\hline Occational (C) & 4 & 6 & 11 & 18 \\
\hline Remote (D) & 8 & 10 & 14 & 19 \\
\hline Improbable (E) & 12 & 15 & 17 & 20 \\
\hline
\end{tabular}

Category 1(1-6). Controlling mitigating or both, actions must be taken to reduce the risk Category 2(7-10). If no mitigation actions taken company can accept the risk Category 3(11-20). Project manager decides on action, if any

Figure 5: Risk matrix.

\begin{tabular}{|c|c|c|c|c|c|c|c|c|}
\hline \multirow[b]{2}{*}{ Subsystem } & \multirow[b]{2}{*}{ Component } & \multirow{2}{*}{$\begin{array}{l}\text { Failure } \\
\text { mode }\end{array}$} & \multirow{2}{*}{$\begin{array}{l}\text { Failure } \\
\text { causes }\end{array}$} & \multicolumn{3}{|c|}{ Effects of failure } & \multirow{2}{*}{ Criticality } & \multirow{2}{*}{$\begin{array}{c}\text { Detection and } \\
\text { mitigation }\end{array}$} \\
\hline & & & & $\begin{array}{l}\text { Effect on other } \\
\text { systems }\end{array}$ & $\begin{array}{c}\text { Effect on overall } \\
\text { system }\end{array}$ & $\begin{array}{c}\text { Effect on HSE and } \\
\text { finance }\end{array}$ & & \\
\hline \multirow[t]{2}{*}{$\begin{array}{c}\text { Transmission } \\
\text { system from } \\
\text { shore }\end{array}$} & $\begin{array}{l}\text { Cable } \\
\text { (static) }\end{array}$ & $\begin{array}{l}\text { Loss of } \\
\text { electricity }\end{array}$ & $\begin{array}{l}\text { Scour and } \\
\text { sediment } \\
\text { migration }\end{array}$ & $\begin{array}{c}\text { Electrical heaters } \\
\text { shutdown }\end{array}$ & \begin{tabular}{|c|} 
Cable \\
disconnected, \\
Gas turbine \\
provides essential \\
power demand \\
\end{tabular} & $\begin{array}{l}\text { Reduction in } \\
\text { production, } \\
\text { Effect on } \\
\text { emission control }\end{array}$ & 6 & $\begin{array}{c}\text { Implement } \\
\text { proper operation } \\
\text { and maintenance } \\
\text { plan }\end{array}$ \\
\hline & $\begin{array}{l}\text { Cable } \\
\text { (static) }\end{array}$ & $\begin{array}{l}\text { Loss of } \\
\text { electricity }\end{array}$ & $\begin{array}{c}\text { Animal } \\
\text { attack (e.g. } \\
\text { whales, } \\
\text { shark etc. })\end{array}$ & - do - & - do - & - do - & 4 & \begin{tabular}{|} 
Route survey, \\
Cable selection \\
for protection of \\
accidental \\
damage
\end{tabular} \\
\hline \multirow[t]{2}{*}{ Gas generator } & $\begin{array}{c}\text { Combustion } \\
\text { chamber }\end{array}$ & Coolant loss & $\begin{array}{c}\text { Manufact. } \\
\text { Process } \\
\text { problem }\end{array}$ & $\begin{array}{l}\text { WHRU } \\
\text { shutdown }\end{array}$ & $\begin{array}{c}\text { Reduced } \\
\text { performance }\end{array}$ & $\begin{array}{c}\text { Burn-through } \\
\text { possible crash and } \\
\text { injury to involved } \\
\text { public }\end{array}$ & 6 & Inspect welds \\
\hline & & Seal failure & $\begin{array}{l}\text { Cyclic } \\
\text { fatigue }\end{array}$ & $\begin{array}{c}\text { Reduced } \\
\text { performance }\end{array}$ & $\begin{array}{c}\text { Reduced } \\
\text { performance }\end{array}$ & & 14 & Seal redundancy \\
\hline
\end{tabular}

Figure 6: $\quad$ FMECA worksheet.

\section{Results and discussion}

The electrification does not cover the total power requirement of this new oil development compared to the other oil fields, which have being completely electrified (e.g. Troll A). This is because the development is partially dependent on the turbine-driven system for satisfying the significantly high heat demand and the need to continue operations at a reduced capacity, in the case of loss of one power source particular as the probability of losing the electric current cannot be disregarded for this location. In addition, the availability of power from national grid to the oil field is rather important to make decisions for electrification.

Therefore, it is vital to qualify the technique selected for this particular oil field to identify the potential failures in each system and their effect on the overall system in the new environment. FMECA is selected as an important tool 
to identify the potential faults of the technique selected. This will help to modify the system in the early phases of the project and serves as a platform and basis for the further work. This risked-based approach can be considered as a valueadding exercise to identify critical failure modes during installations, execution and production phases of the techniques' applications and their impact on the environment, finance and society. The FMECA will also help to develop a mitigation plan for the majority of the perceived risks. However, it is extremely difficult to identify every possibility for potential failures although this framework provides, in our opinion, the rigorous best approach. Nevertheless, this method does not account for the consequences of co-existing, multi-element faults and failures and human errors.

\section{Acknowledgements}

The authors are grateful for valuable support received from Liv Nielsen from Eni Norge AS, Norway.

\section{References}

[1] Bellona. Environment and Value Creation; $\mathrm{CO}_{2}$ for $\mathrm{EOR}$ on the Norwegian shelf (A case study), 2005 report, Oslo, Norway.

[2] NPD (Norwegian Petroleum Directorate), www.npd.no.

[3] FACTS. The Norwegian Petroleum Sector, Ministry of Petroleum and Energy, Oslo, Norway, 2008.

[4] Villasenor, R., Magdaleno, M., Quintanar, A., Gallardo, J. C., López, M. T., Jurado, R., Miranda, A., Aguilar, M., Melgarejo, L. A., Palmerín, E., Vallejo, C. J. \& Barchet, W. R. An air quality emission inventory of offshore operations for the exploration and production of petroleum by the Mexican oil industry. Atmospheric Environment, 37(26), pp. 3713-3729, 2003.

[5] Simeonova, K. \& Diaz-Bone, H. Integrated climate-change strategies of industrialized countries. Energy, 30(14), pp. 2537-2557, 2005.

[6] Petroleum Safety Authority (PSA), Regulations relating to Design and Outfitting of Facilities in the Petroleum Activities (the Facilities Regulations), PSA, Stavanger, Norway, 2008.

[7] Hasle J.R., Kjellén U. \& Haugerud O. Decision on oil and gas exploration in an Arctic area: Case study from the Norwegian Barents Sea. Safety Science, In Press, Corrected Proof, 2008.

[8] Ekins P., Vanner, R. \& Firebrace, J. Zero emissions of oil in water from offshore oil and gas installations: economic and environmental implications. Journal of Cleaner Production, 15(13-14), pp.1302-1315, 2007.

[9] Lamell, J.O., Trumbo, T. \& Nestli, T.F. Offshore platform powered with new electrical motor drive system, Proc. of the $52^{\text {nd }}$ Annual Technical Conference of the Petroleum and Chemical industry Committee Denver, 2005 . 
[10] Schollenberger, H., Treitz, M. \& Geldermann, J. Adapting the European approach of Best Available Techniques: case studies from Chile and China. Journal of Cleaner Production, 16(17), pp.1856-1864, 2008.

[11] Mirasgedis, S., Hontou V., Georgopoulou, E., Sarafidis, Y., Gakis, N. \& Lalas, D.P. Environmental damage costs from airborne pollution of industrial activities in the greater Athens, Greece area and the resulting benefits from the introduction of BAT. Environmental Impact Assessment Review, 28(1), pp. 39-56, 2008.

[12] IPPC. Council Directive 2008/1/EC concerning integrated pollution prevention and control. Official Journal of EU, L 24, pp. 8-29, 2008.

[13] Samarakoon, S.M.S.M.K. \& Gudmestad, O.T. Extending the IPPC directives by implementing a requirement to technique qualification. Journal of Cleaner Production (submitted 14/05/2009).

[14] Buede, D.M. The Engineering design of systems: Models and Methods, Wiley-Interscience publication, pp. 229-358, 2000.

[15] DNV. Recommended Practice DNV-RP-A203, Qualification Procedures for New Technology, Oslo, Norway, 2001.

[16] Pillay, A. \& Wang, J., Technology and safety of marine systems, Elsevier Science Ltd; Elsevier Ocean Engineering Book Series Volume 7,pp. 1115, 2003.

[17] De Alegría, I. M., Martín, J. L., Kortabarria, I., Andreu, J. \& Ereño, P. I. Transmission alternatives for offshore electrical power. Renewable and Sustainable Energy Reviews, 13, pp. 1027-1038, 2009.

[18] Chohawala, R. DC transmission to offshore installations. The Journal of offshore Technology, 12, pp. 4-9, 2004.

[19] Sheehan, J. Gjøa Development Opens New Frontier. Journal of Petroleum Technology, April, pp.38-40, 2009.

[20] Gudmestad, O. T \& Strass, P. In Technological challenges for hydrocarbon production in the Barents Sea. Power Technology and Engineering (formerly Hydrotechnical Construction), 28(8), pp.460-471, 1994. 